\title{
Degradation of Nitrogen, Phosphorus, and Organic Matter in Urban River Sediments by Adding Microorganisms
}

\author{
Fan Wang ${ }^{1}$, Yangwei Bai ${ }^{1}$, Fang Yang ${ }^{1,2, *}$, Qiuheng Zhu ${ }^{1,2}$, Qianyu Zhao ${ }^{2}$, Xiaojiao Zhang ${ }^{3}$, Yimei Wei ${ }^{1}$ \\ and Haiqing Liao ${ }^{1,2, *}$ \\ 1 Basin Research Center for Water Pollution Control, Chinese Research Academy of Environmental Sciences, \\ Beijing 100012, China; hjwfsd@163.com (F.W.); baiyw@craes.org.cn (Y.B.); qiuheng_zhu@163.com (Q.Z.); \\ wei.yimei@craes.org.cn (Y.W.) \\ 2 State Key Laboratory of Environmental Criteria and Risk Assessment, Chinese Research Academy of \\ Environmental Sciences, Beijing 100012, China; 412514819044@email.ncu.edu.cn \\ 3 College of Fisheries and Life Science, Dalian Ocean University, Dalian 116023, China; \\ zhangxiaojiao47@163.com \\ * Correspondence: yang.fang@craes.org.cn (F.Y.); liaohq@craes.org.cn (H.L.)
}

Citation: Wang, F.; Bai, Y.; Yang, F.; Zhu, Q.; Zhao, Q.; Zhang, X.; Wei, Y.; Liao, H. Degradation of Nitrogen, Phosphorus, and Organic Matter in Urban River Sediments by Adding Microorganisms. Sustainability 2021, 13, 2580. https://doi.org/10.3390/ su13052580

Academic Editor: Ifigenia Kagalou

Received: 8 February 2021

Accepted: 24 February 2021

Published: 28 February 2021

Publisher's Note: MDPI stays neutral with regard to jurisdictional claims in published maps and institutional affiliations.

Copyright: (c) 2021 by the authors. Licensee MDPI, Basel, Switzerland. This article is an open access article distributed under the terms and conditions of the Creative Commons Attribution (CC BY) license (https:// creativecommons.org/licenses/by/ $4.0 /)$.

\begin{abstract}
Reducing and remediating endogenous sediment pollution in urban rivers using appropriate microbiological remediation technology is regarded as a safe, effective, and environmentally sustainable mechanism. In this study, the pollutant removal efficiency of three microorganism types at different dosages was studied in the laboratory. To optimize the microbial restoration scheme, a comprehensive analysis of their effectiveness in removing total nitrogen (TN), total phosphorus (TP), total organic matter (OM), and polycyclic aromatic hydrocarbons (PAHs) was conducted, and associated structural changes in the sediment bacteria were analyzed. The results showed that using nitrifying bacteria and Bacillus as microbial agents resulted in superior removal efficiencies of TN and TP in sediments, whereas yeast was not as effective. The removal rates of TN reached $27.65 \%$ and $20.88 \%$ when $5 \mathrm{mg}$ nitrifying bacteria and $10 \mathrm{mg}$ Bacillus respectively, were used. A comparative analysis showed that nitrifying bacteria exhibited a better TN removal effect; however, Bacillus exhibited a better TP removal effect. The results of high-throughput sequencing revealed no significant changes to the microbial community structures when optimal microorganisms or beneficial microorganisms that thrive using $\mathrm{OM}$ as a source of $\mathrm{C}$ and energy were added. This study provides insights into the processes and mechanisms involved in the microorganism degradation of black and odorous sediment, and the results can be used as a basis for developing endogenous pollution control policies and methods for urban rivers.
\end{abstract}

Keywords: endogenous treatment; microbiological remediation; degradation; high-throughput sequencing; Bacillus

\section{Introduction}

Rapid regional urbanization in China has caused soil erosion, water quality deterioration, ecological damage [1], and an increase in the amount of sewage being discharged into urban water bodies. The lack of urban infrastructure and the highly centralized nature of the population and industries have also caused increased amounts of pollutants being discharged into the water systems that are beyond the capacity of water bodies to self-purify, and this has caused a deterioration in water quality that has led to the development of the phenomenon known as "black and odorous water (black-odorous water)" [2,3]. Blackodorous water not only damages aquatic ecosystems but also pollutes the atmospheric environment and threatens human health.

Black-odorous water is a worldwide common event especially in less developed areas. It has been reported in Indonesia [4], Malaysia [5], Pakistan [6], India [7], and Vietnam [8]. 
South Korea has taken three measures including dredging, comprehensive sewage interception, and water conservation to treat Cheongchon Stream. Germany has vigorously carried out rain and sewage diversion reconstruction and sewage treatment facilities construction, adopted measures such as "sewage elevator", green embankment, and river treatment to restore the severely polluted Emscher River, and coordinated management of water environment and water resources. France adopts measures such as source control and pollution interception, sewer improvement, non-point source pollution reduction, river water replenishment, and storage to treat the Seine River in Paris. Austria has managed its Danube River by building ecological dikes and optimizing the allocation and use of water resources [9].

In China, based on data obtained from the National Urban Black-Odorous Water bodies Governance and Supervision Platform [10], black-odorous water bodies have been reported in most provinces across China and are a matter of environmental and social concern. The Chinese government attaches great importance to the treatment of blackodorous water bodies, and the remediation of such water bodies is one of the important tasks stipulated in the government's action plan for preventing and controlling water pollution. In this respect, there were 2869 black-odorous water bodies nationwide in 2017; however, by the end of 2019, 2313 black-odorous water bodies in 295 cities at or above prefecture level had been resolved [10].

Based on the previous research, ferrous sulfide and manganese sulfide are the main substances causing the blackening of waterbodies [11,12], while volatile organic sulfur compounds are largely responsible for odor formation [13]. External and internal pollution sources contribute to the development of black-odorous water [14-16]. Sediments are the sources and sinks of endogenous pollutants $[17,18]$ : pollutants in sediments are released into the water body, and pollutants within the water body also settle onto sediments $[19,20]$. Therefore, it is first necessary to control exogenous pollution and then remove endogenous pollution within urban rivers by treating the sediments therein [21,22]. In-situ remediation technology for sediments has been widely studied due to its rapid effect and low cost [16-18]. In this respect, microbial treatment is an effective biological method used to eliminate pollutants [23]. The bioremediation of polluted urban rivers is achieved by using specific organisms (particularly microorganisms) to absorb, transform, or degrade pollutants to reduce water pollution and restore the ecological function of the water $[11,20]$. Many studies have focused on the use of microbial treatments to treat black-odorous wastewater and prevent the eutrophication of water bodies; however, relatively few have focused on the remediation effect of microorganisms acting directly on sediments [24]. For example, many studies have shown that denitrifying bacteria, nitrifying bacteria, photosynthetic bacteria, bacilli, and other microorganisms are effective in treating polluted river water [25].

Different microorganisms have different removal effects on nitrogen $(\mathrm{N})$, phosphorus $(\mathrm{P})$, organic matter $(\mathrm{OM})$, and polycyclic aromatic hydrocarbons (PAHs) in sediments. PAHs are the most carcinogenic environmental pollutants in sediments and are, thus, the focus of many studies. Microbes can degrade PAHs under aerobic conditions; however, they also use an anaerobic mechanism. Nitrifying bacteria are mostly used in the removal of total N (TN); however, yeast is often used in the removal of organic pollutants and PAHs, and Bacillus is mostly used in the removal of total P (TP). Nitrifying bacteria play an important role in the denitrification of sediments. $\mathrm{NH}_{4}{ }^{+}$is converted into $\mathrm{N}$ in the form of nitrate under the action of nitrifying bacteria, and the nitrate is further converted into gaseous $\mathrm{N}$ by denitrifying bacteria $[26,27]$. Therefore, to develop the optimal microbial remediation scheme that provides a sustainable river ecosystem without impacting the original microbial structure of the river sediment, it is necessary to select specific microorganisms that can control water-sediment pollution [28-30]. It is also important to use the correct microbial dosage to enable the effective removal of different pollutants in urban river sediments [31]. 
Although there are few studies [32-35] focused on the remediation of sediments by microorganisms, nearly no studies have compared the pollutant removal effects of three different bacteria on the same sediment. To identify a suitable remediation scheme and provide reliable data and theoretical support for the microbial treatment of endogenous pollution in urban rivers, three common and harmless microbial agents (nitrifying bacteria, yeast, and Bacillus) that have wide applications in controlling environmental pollution were selected in this study to directly remediate polluted river sediment, and their application at different dosages was assessed. To identify a suitable strategy for use in the bioremediation of black-odorous water in urban rivers, the controlling effects of three microbial agents on endogenous pollution were then analyzed and the extent of sediment pollutant removal and changes in microbial community structure were explored under different doses of these microbial agents.

In this study, sediments and the overlying water were collected from the North Canal (see Figure 1) as samples: 16 sediments samples and 16 overlying water samples were collected in total. The North Canal is a part of the Beijing-Hangzhou Grand Canal and an important part of the flood control system of the Haihe River basin [36]. It flows through Beijing, Tianjin, and Hebei provinces. Dredging of the main channel of the North Canal is expensive and ecologically destructive; hence, it is not a suitable method for maintaining the long-term health of the river water. It is thus necessary to improve the self-purification ability and environmental capacity of the rivers and rebuild its benign circulation using microbial remediation techniques. This study aims to select different agents according to different pollutants, thus providing a possible solution to the pollution of the North Canal water sediments. The research results may be applied to the pollution control of black-odorous water sediment in urban areas after large-scale development.

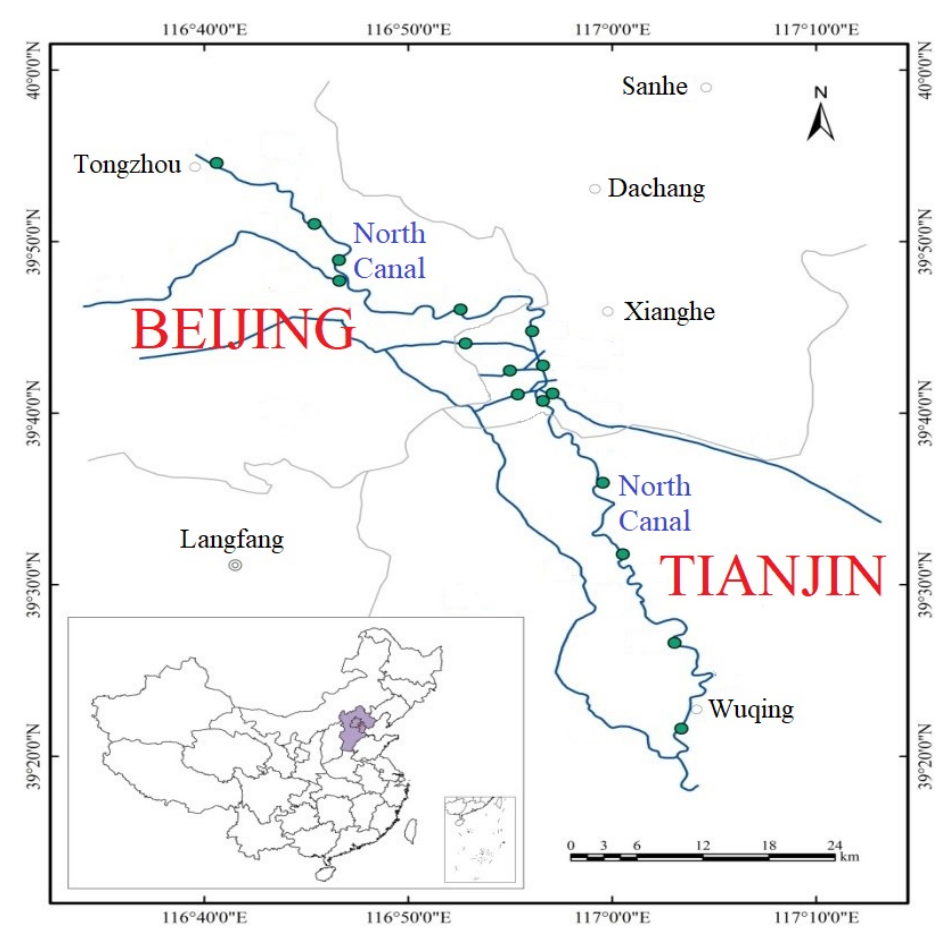

Figure 1. The map of the study area-North Canal.

\section{Materials and Methods}

\subsection{Sample Collection and Pretreatment}

Sediment samples collected from the North Canal were stored in a refrigerator $\left(-80^{\circ} \mathrm{C}\right)$ until completely dry, and rock, branches, and other types of debris were removed from them. The sediments were then evenly mixed, and a part of the sample was cryogenically 
freeze-dried. High-throughput sequencing was conducted before and after the experiment to analyze the microbial community structure to detect any changes.

\subsection{Experiment Design and Execution}

Sediment samples were placed in a column up to a height of $20 \mathrm{~cm}$, and $30 \mathrm{~cm}$ of overlying water was then injected by siphon. The column was wrapped in tinfoil to protect the contents from the exposure to light. The amount of water reduced due to sampling and daily evaporation was replenished throughout the experimental period.

The microbial experiment used 13 experimental columns: 1 column was used as the control and the remaining 12 columns were divided into three groups, each using one type of microbial agent. The three sets of experiments involved treatment with nitrifying bacteria, yeast, and Bacillus respectively, and four different microbial concentrations were used (one in each of the four columns). The specific dosages of microbial agents are shown in Table 1.

Table 1. Dosage of microbial agent.

\begin{tabular}{|c|c|c|c|c|c|c|c|c|c|c|c|c|c|}
\hline \multirow{2}{*}{$\begin{array}{c}\text { Group } \\
\text { Serial name }\end{array}$} & \multirow{2}{*}{$\begin{array}{c}\text { Control } \\
\text { Group }\end{array}$} & \multicolumn{4}{|c|}{$\begin{array}{c}\text { Nitrifying Bacteria } \\
\text { Treatment }\end{array}$} & \multicolumn{4}{|c|}{$\begin{array}{c}\text { Yeast } \\
\text { Treatment }\end{array}$} & \multicolumn{4}{|c|}{$\begin{array}{l}\text { Bacillus } \\
\text { Treatment }\end{array}$} \\
\hline & & S1 & S2 & S3 & $\mathrm{S} 4$ & $\mathrm{~J} 1$ & $\mathrm{~J} 2$ & $\mathrm{~J} 3$ & $\mathrm{~J} 4$ & $\mathrm{~K} 1$ & $\mathrm{~K} 2$ & K3 & $\mathrm{K} 4$ \\
\hline Dosage (mg) & 0 & 5 & 10 & 20 & 50 & 5 & 10 & 20 & 50 & 5 & 10 & 20 & 50 \\
\hline
\end{tabular}

The reaction device (height and diameter of 50 and $15 \mathrm{~cm}$, respectively) used to simulate internal control was made of transparent organic glass and is shown in Figure 2. The sampling ports were set in four directions every $10 \mathrm{~cm}$ from the top to the bottom during the experiment, whereas those at 30 and $40 \mathrm{~cm}$ on one side were used to draw water samples. All sampling ports were taped with a rubber holster and clamped with a water stopper.

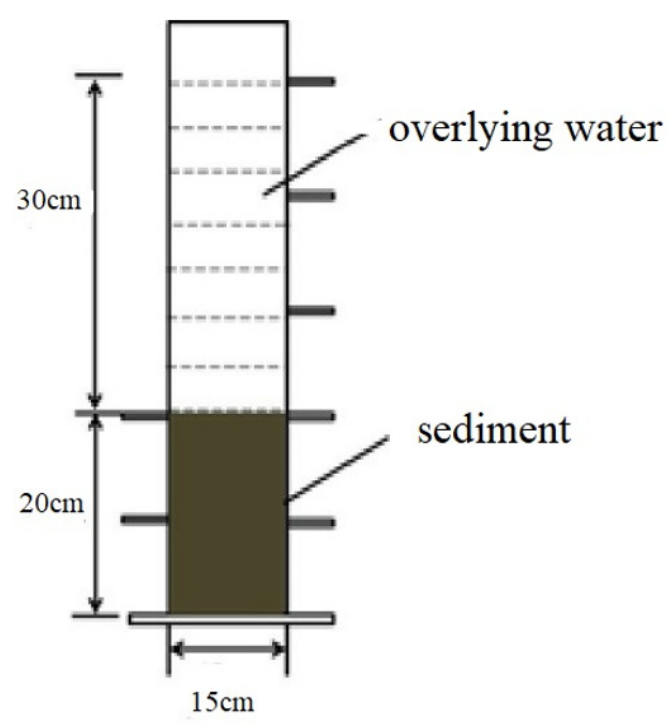

Figure 2. Experimental set up.

The experiment was run for six weeks, and the indices for TN, TP, OM, and PAHs in the sediments were obtained every two weeks and analyzed according to HJ 634-2012 [37], HJ 632-2011 [38], HJ 658-2013 (Chinese Ministry of Ecology and Environment 2013) [39], and HJ 784-2016 [40] specifications, respectively. TN was measured by extraction with potassium chloride solution-spectrophotometric methods using spectrophotometer with $10 \mathrm{~mm}$ colorimetric dish. The main reagents were potassium chloride, hydrochloric acid 
$\mathrm{N}$-(1-naphthyl)-ethylenediamine, sulfonamide, etc. TP was measured by alkali fusion-Mo$\mathrm{Sb}$ anti-spectrophotometric method using a spectrophotometer with $30 \mathrm{~mm}$ colorimetric dish. The main reagents were sodium hydroxide, ammonium molybdate, potassium dihydrogen phosphate, etc. OM was measured by combustion oxidation-titration method using tube furnace and acid burette. The main reagents were hydrochloric acid, barium hydroxide, phenolphthalein, etc. PAHs was measured by high-performance liquid chromatography using high-performance liquid chromatograph. The main reagents were acetonitrile, n-hexane, methylene chloride, etc. In the 1980s, the US Environmental Protection Agency (EPA) listed 16 kinds of PAHs without branches as environmental priority pollutants, including acenaphthene, acenaphthylene, anthracene, benzo(a)anthracene, benzo(a)pyrene, benzo(b)fluoranthene, benzo(g,h,i)perylene, benzo(k)fluoranthene, chrysene, dibenzo(a,h)anthracene, fluoranthene, fluorene, indeno(1.2.3-cd)pyrene, naphthalene, phenanthrene, and pyrene.

\subsection{Microbial Agent Inoculation}

Three microbial agents (nitrifying bacteria, yeast, and Bacillus) were used in the experiment. The nitrifying bacteria agent (Shanghai BLAQN Biotechnology Co., Ltd., Shanghai, China) was a grey powder and it contained mainly nitrifying bacteria, nutrients, and biological enzymes, and it had an effective bacteria content greater than $5 \times 10^{9} \mathrm{cfu}$ (Colony-Forming Unit)/g. The yeast (Shanghai BLAQN Biotechnology Co., Ltd.) was a yellow powder containing mainly yeast, nutrition, and enzymes, and had an effective bacterial content greater than $5 \times 10^{9} \mathrm{cfu} / \mathrm{g}$. The agent containing Bacillus (Guangzhou Liuhui Biotechnology Co., Ltd., Guangzhou, Guangdong, China) was a fine light-yellow powder with a bran matrix and an effective viable Bacillus count greater than $5 \times 10^{9} \mathrm{cfu} / \mathrm{g}$.

\subsection{High-Throughput Sequencing Data Analysis}

The genomic DNA of the microbial communities was extracted from sediment samples using $1 \%$ agarose gel, and the DNA concentration and purity were determined using a NanoDrop 2000 UV-vis (Ultraviolet and visible spectrophotometry) spectrophotometer (Thermo Scientific, Wilmington, USA). The hypervariable region V3-V4 of the bacterial $16 \mathrm{~S}$ rRNA gene was amplified with primer pairs 338F (5'-ACTCCTACGGGAGGCAGCAG$\left.3^{\prime}\right)$ and 806R (5'-GGACTACHVGGGTWTCTAAT-3') using an ABI GeneAmp ${ }^{\circledR} 9700$ PCR (Polymerase Chain Reaction) thermocycler (ABI, Los Angeles, CA, USA), with paired-end sequencing conducted on an Illumina MiSeq PE300 platform/NovaSeq PE250 platform (Illumina, San Diego, CA, USA) according to the standard protocols of the Majorbio BioPharm Technology Co., Ltd. (Shanghai, China). Operational taxonomic units (OTUs) differentiated with a $97 \%$ similarity cutoff [41] were clustered using UPARSE version 7.1 [42], and chimeric sequences were identified and removed. The taxonomy of each OTU representative sequence was analyzed using an RDP (Ribosomal Database Project) Classifier version 2.2 [43] against the $16 \mathrm{~S}$ rRNA database (e.g., Silva v138), employing a confidence threshold of 0.7 .

\section{Results}

\subsection{Nitrogen (N) Removal Efficiency}

As shown in Figure 3, the TN concentrations of sediments began to decrease after the microbial agents were added. The TN concentration of the control group decreased from 781.36 to $683.14 \mu \mathrm{g} / \mathrm{g}$ over the six weeks, with a removal rate of $12.57 \%$. In the experimental group treated with nitrifying bacteria (columns S1 to S4), the TN removal rates corresponding to $5,10,20$, and $50 \mathrm{mg}$ of nitrifying bacteria were $27.65 \%, 24.87 \%$, $15.14 \%$, and $15.54 \%$, respectively. Thus, the optimal treatment effect was achieved with a nitrifying bacteria dose of $5 \mathrm{mg}$, and the TN concentration in the sediments decreased from 782.13 to $565.87 \mu \mathrm{g} / \mathrm{g}$. This effect was $15.08 \%$ higher than that of the control group. 

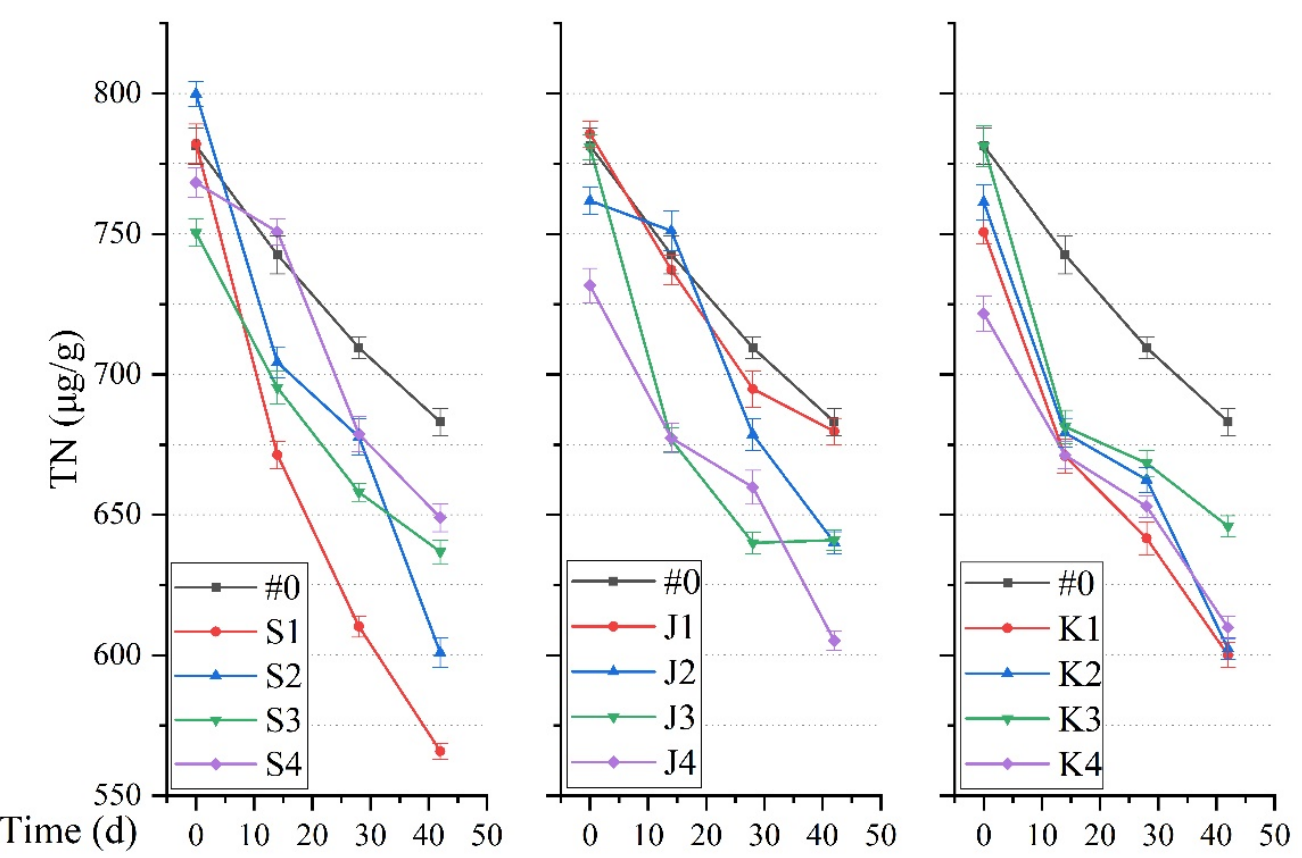

Figure 3. Variation of total nitrogen (TN) in sediments.

Studies have shown that, compared with the untreated system, the removal rate of $\mathrm{N}$ present in the form of ammonia increases by $18 \%$ in the first $4 \mathrm{~h}$ after inoculating with nitrifying bacteria [44]. Therefore, the TN concentration of sediments began to decrease when nitrobacteria were added to S1-S4. The rate of the nitrification process of sediments increased with an increase in the number of nitrifying bacteria in the system, and the nitrification activity subsequently became enhanced.

The removal rates of TN in the yeast experimental group (corresponding to J1 to J4) were as low as $13.48 \%, 15.98 \%, 17.91 \%$, and $17.29 \%$ respectively, $0.91 \%$ to $5.34 \%$ higher than that in the control group. Therefore, there were no obvious TN removal effects observed when yeast was added to sediments. Chang [45] conducted field experiments on blackodorous water by adding yeast and found that there was very little change in the amount of TN in the yeast-added sediments, which implies that the addition of yeast has little effect on TN in sediments [46].

The final treatment rates in the Bacillus experimental group (corresponding to K1-K4) were $20.06 \%, 20.88 \%, 17.33 \%$, and $15.50 \%$, respectively. The removal rate of TN was the highest at a dosage of $10 \mathrm{mg}$ ( $\mathrm{TN}$ concentration in the sediments decreased from 761.28 to $602.31 \mu \mathrm{g} / \mathrm{g}$ ). The proliferation of bacilli leads to the production of a large quantity of extracellular enzymes that decompose the $\mathrm{OM}$ (such as starch, protein, and fat in sediments) and, thus, reduce the amount of OM in eutrophic water bodies, thereby reducing the risk of eutrophication [47]. During the decomposition process, a part of the OM is converted into the cellular matter of bacilli; however, much of the OM is converted into energy used by the bacteria. In addition, $\mathrm{OM}$ is released from the water in the form of $\mathrm{N}$ and $\mathrm{CO}_{2}$ to reduce the amount of ammonia-nitrogen and nitroso-nitrogen in the water and restore the dissolved O levels in the water body [46].

The results of this experimental phase show that nitrifying bacteria and Bacillus were successful in removing TN from river sediments, and they were thus selected as prospective microbial agents. With nitrifying bacteria and Bacillus doses of 5 and $10 \mathrm{mg}$ respectively, the removal rates of $\mathrm{TN}$ were as high as $27.65 \%$ and $20.88 \%$, which were $15.08 \%$ and $8.31 \%$ higher than for the control group, respectively.

\subsection{Phosphorus (P) Removal Efficiency}

The concentration of TP showed a declining trend during the action of all three microorganisms on the sediments (Figure 4). In the control group without any treatment, 
the microbial concentration in sediments decreased from 523 to $422.78 \mu \mathrm{g} / \mathrm{g}$, and the TP removal rate was $19.16 \%$. The sediment originally contained native microorganisms; therefore, beneficial microorganisms in the sediments would have multiplied and consumed the polluting substances at appropriate temperatures [48].
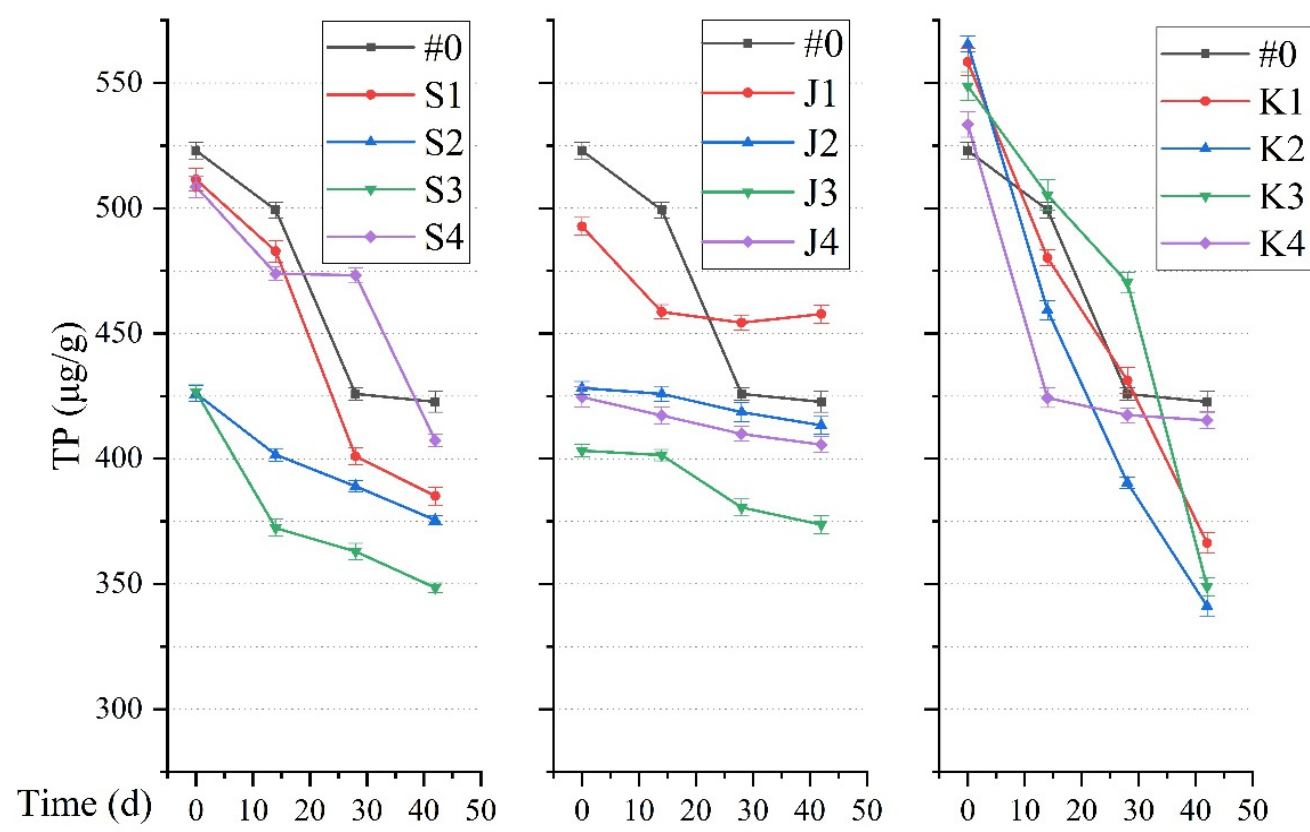

Figure 4. Variation of total phosphorous (TP) in sediments.

The aim of adding microbial agents into sediments is primarily to use the microorganisms (or their influence on indigenous microorganisms in the sediments) to decompose pollutants. Figure 4 shows the changes in the TP concentration that occurred when the nitrifying bacteria were acting on the sediments. The removal rates of TP in sediments were $24.70 \%, 11.87 \%, 18.36 \%$, and $19.90 \%$, with doses of $5,10,20$, and $50 \mathrm{mg}$, respectively. With a nitrobacteria dosage of $5 \mathrm{mg}$, the concentration of TP decreased from 511.44 to $385.12 \mu \mathrm{g} / \mathrm{g}$, and the removal rate was thus $5.54 \%$ higher than the control group, which confirms that nitrifying bacteria can remove TP from sediments.

However, the TP removal rates were as low as 7.09\%, 3.47\%, 7.33\%, and $4.47 \%$ respectively, when yeast was added to the sediments (columns J1 to J4). This result reflects the effect of yeast on sediments. Yeast produces a special enzyme that decomposes organic macromolecular substances into simple small-molecule OM that, then, remains in the sediments. Furthermore, the addition of yeast may have little effect on beneficial microorganisms in the sediment because no synergistic relationship exists between them [49].

With the addition of Bacillus, the TP removal rates were $34.40 \%, 39.67 \%, 36.42 \%$, and $22.14 \%$, with dosages of $5,10,20$, and $50 \mathrm{mg}$, respectively. The highest TP removal rate corresponded to the dosage of $10 \mathrm{mg}$, and the concentration of TP decreased from 565.50 to $341.16 \mu \mathrm{g} / \mathrm{g}$.

In conclusion, the results of microorganism type and dosage efficiency experiments show that $5 \mathrm{mg}$ of nitrifying bacteria and $10 \mathrm{mg}$ of Bacillus are the ideal microbial doses for removing TP from sediments. The TP removal rates were as high as $24.70 \%$ and $39.67 \%$ respectively, when these doses were used $(5.54 \%$ and $20.51 \%$ higher than the control, respectively).

\subsection{Variations in OM and PAH Contents during Microbial Treatment}

Extracellular enzymes are used by microbes to decompose and degrade the OM in sediments. The variation in the OM content of sediments during microbial treatment is shown in Figure 5. The results show that OM removal rates by nitrifying bacteria were 
$19.76 \%, 24.40 \%, 22.26 \%$, and $13.74 \%$ respectively, and the maximum removal rate was $6.71 \%$ higher than for the control. The removal rates for OM by yeast were $11.76 \%, 21.80 \%$, $22.07 \%$, and $13.36 \%$ respectively, and those by Bacillus were $18.91 \%, 17.14 \%, 18.28 \%$, and $13.97 \%$ respectively, where the maximum removal rate was $1.22 \%$ higher than for the control. These results show that microbial agents partially degrade the OM in sediments; however, impurities are introduced when they are added in excess, which reduces the removal of OM [50].
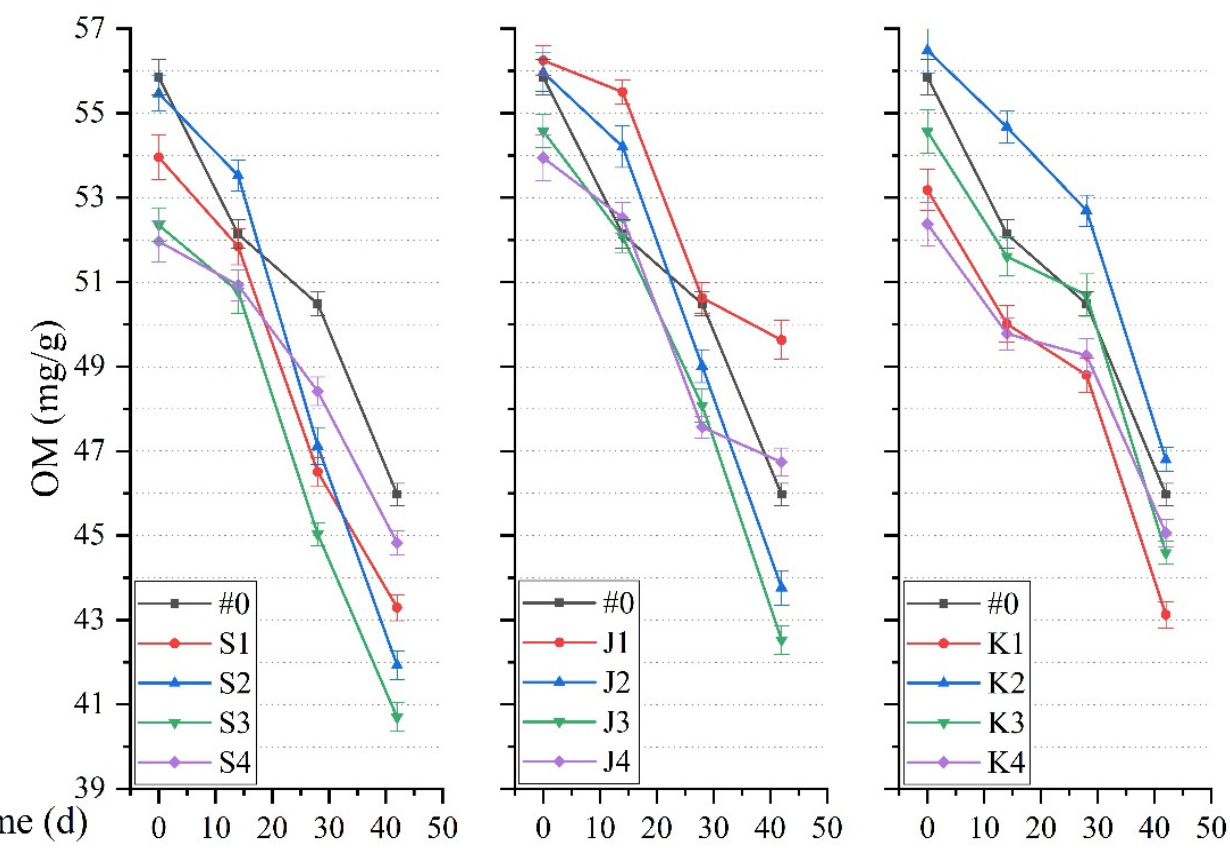

Figure 5. Variation of organic matter $(\mathrm{OM})$ in sediments.

The removal rates of four kinds of PAHs are shown in Table 2. In the control group, the removal rates of phenanthrene, fluorene, fluoranthene, and benzo(a)anthracene were $2.92 \%, 1.95 \%, 1.50 \%$, and $1.02 \%$, respectively. When $5 \mathrm{mg}$ of nitrifying bacteria was added, the removal rates of phenanthrene, fluorene, fluoranthene, and benzo(a)anthracene were $6.34 \%, 4.21 \%, 1.82 \%$, and $1.55 \%$ : these results were $3.42 \%, 2.26 \%, 0.32 \%$, and $0.53 \%$ higher than the control, respectively. When $10 \mathrm{mg}$ of yeast was added, the removal rates of phenanthrene, fluorene, fluoranthene, and benzo(a)anthracene were $5.12 \%, 3.98 \%$, $1.74 \%$, and $1.20 \%$ respectively, and these were $2.2 \%, 2.03 \%, 0.24 \%$, and $0.18 \%$ higher than the control, respectively. Furthermore, when $10 \mathrm{mg}$ of Bacillus was added, the removal rates of phenanthrene, fluorene, fluoranthene, and benzo(a)anthracene were $5.59 \%, 4.56 \%, 1.80 \%$, and $1.31 \%$, respectively $(2.67 \%, 2.61 \%, 0.3 \%$, and $0.29 \%$ higher than the control, respectively).

Table 2. Removal rates of four kinds of polycyclic aromatic hydrocarbons (PAHs) when adding different kinds and dosages of microbial agents.

\begin{tabular}{ccccc}
\hline Microbial Agents & Phenanthrene & Fluorene & Fluoranthene & Benzo(a)anthracene \\
\hline Control group (\%) & 2.92 & 1.95 & 1.50 & 1.02 \\
5 mg of nitrifying bacteria (\%) & 6.34 & 4.21 & 1.82 & 1.55 \\
10 mg of yeast (\%) & 5.12 & 3.98 & 1.74 & 1.20 \\
10 mg of Bacillus (\%) & 5.59 & 4.56 & 1.80 & 1.31 \\
\hline
\end{tabular}




\subsection{Microbial Community Structure in Sediments}

The common and unique OTUs of samples were analyzed based on the OTU clustering analysis results. When the number of samples was greater than 5, all samples were homogenized and a Venn diagram was drawn (Figure 6), where each circle is representative of the following sample states: CK2 represents the initial state, Mic2.1 represents the state after natural restoration, Mic2.2 represents the state with nitrifying bacteria, Mic2.3 with yeast, and Mic2.4 with Bacillus. The number of overlapping circles represents the number of OTUs common among the samples, and the number of non-overlapping circles represents the number of unique OTUs in samples. Figure 6 shows that the five samples had 1203 OTUs in common, thus representing 32.8\% of the total number of OTUs (3668), and this indicates that the microbial community structures of the sediment samples were relatively similar.

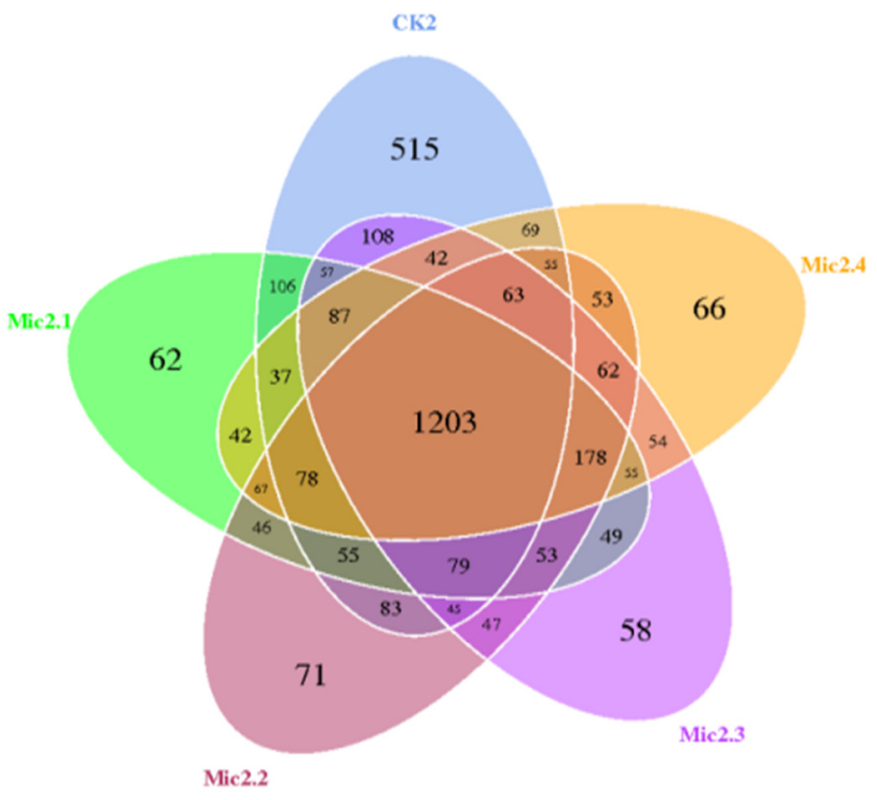

Figure 6. Venn diagram showing microbial community structure of 5 samples based on operational taxonomic units (OTUs).

A weighted Unifrac distance matrix was used in the UPGMA (Unweighted Pair-group Method with Arithmetic Mean) clustering analysis to characterize the differences in community structures and the results are shown in Figure 7. A phylum-level analysis of the five groups of samples showed that only minimal changes occurred in the microbial community structure after six weeks. Based on species annotation and the available abundant information at a genus level, the top 35 ranked genera of all samples were selected. Then, clustering was conducted for both species and samples using the abundant information available for each sample; a heat map was drawn (Figure 8), and species with higher or lower concentrations in the samples were compared and analyzed. As shown in Figure 8, the dominant interspecific microbial species of CK2 (Nitrosomonas, Geobacter, ThioBacillus, Terrimonas, and Sulfuricurvum) lost their advantages, whereas Actibacter, Flavobacterium, Syntrophus, and Sulfuritalea in samples Mic2.1, Mic2.2, Mic2.3, and Mic2.4 gradually dominated. 


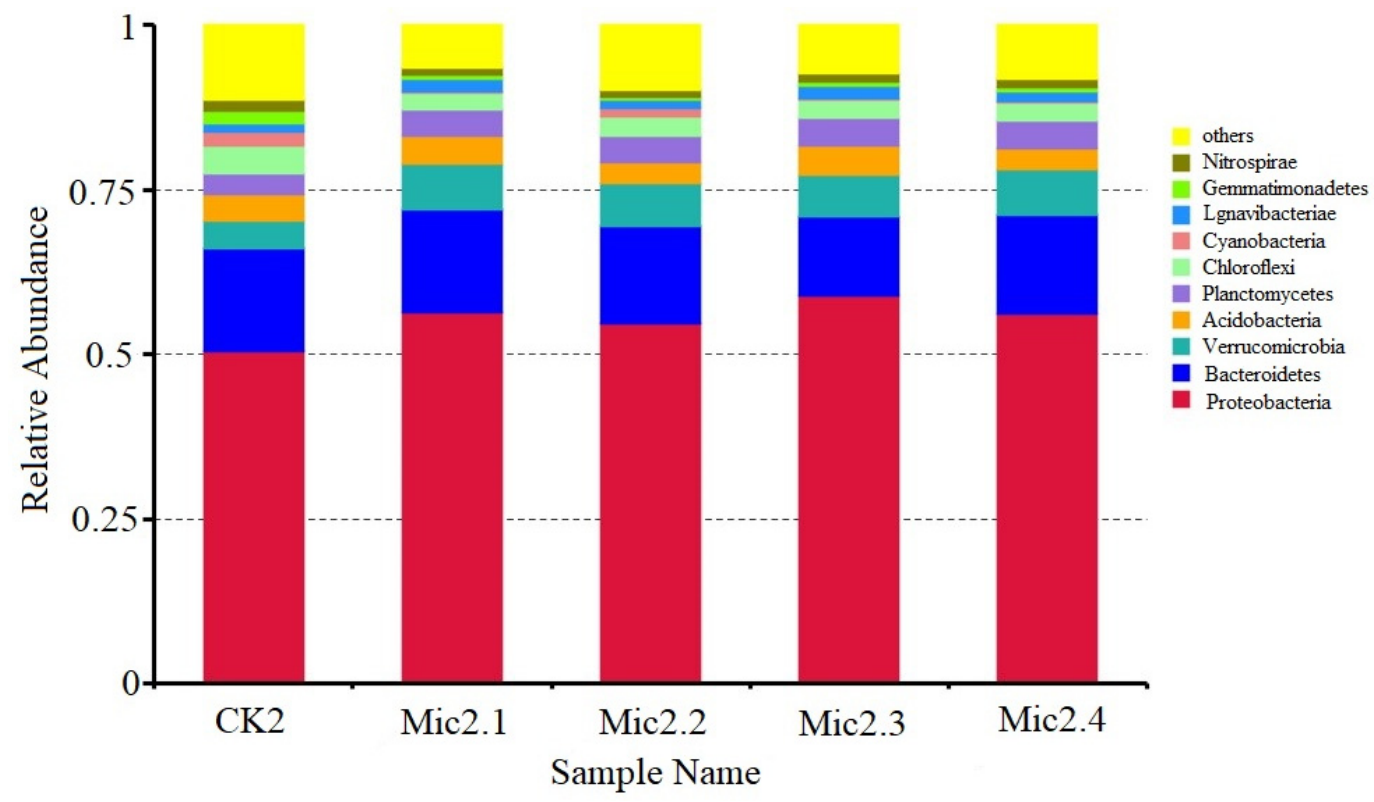

Figure 7. Clustering tree of UPGMA.

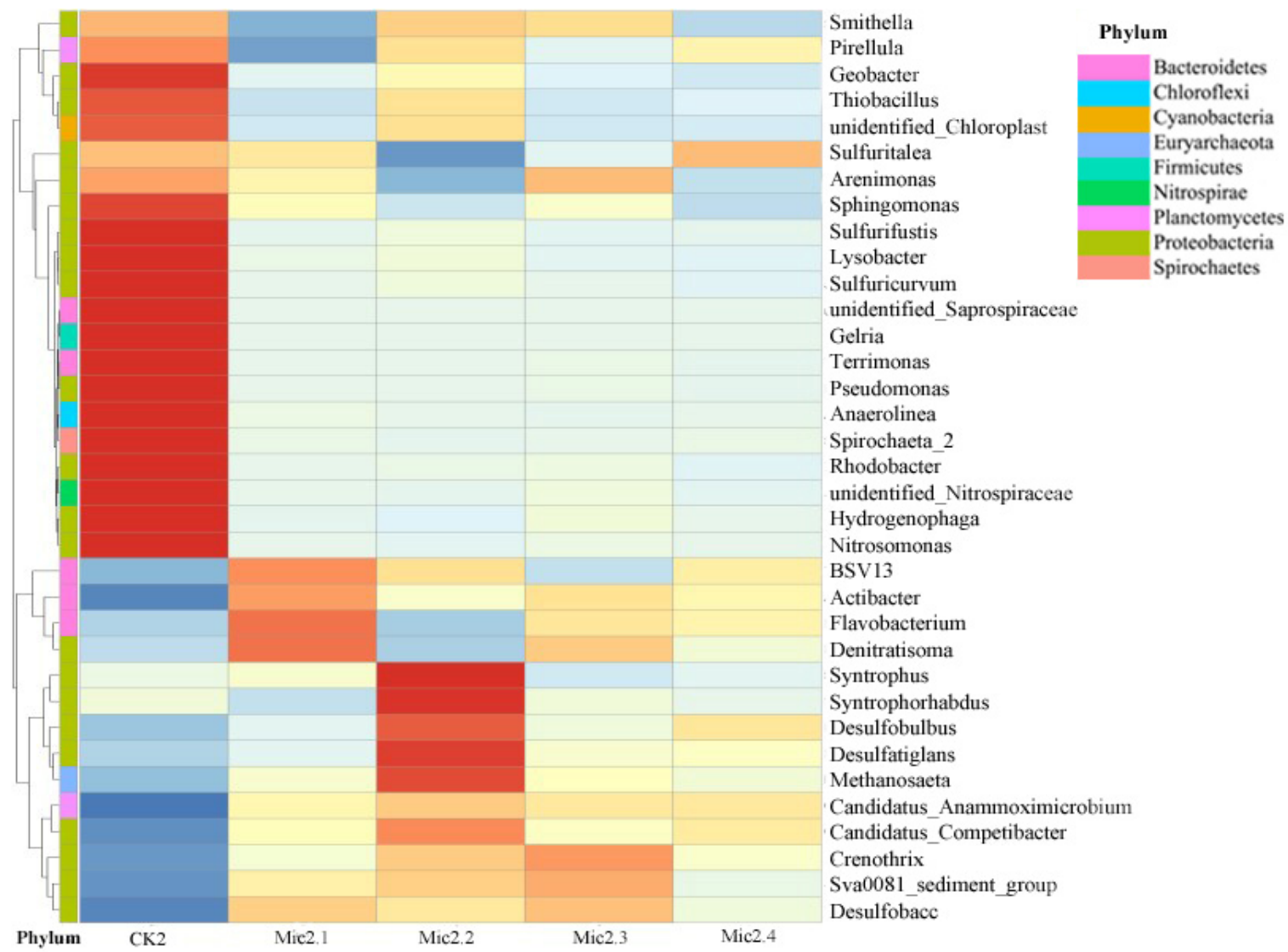

Figure 8. Clustering diagram of species abundance.

\section{Discussion}

4.1. Removal of TN and TP by Denitrifying Bacteria

The three microorganisms exhibit specific degradation behaviors in relation to specific pollutants with respect to their growth and metabolism. For example, nitrifying bacteria play an important role in the denitrification of sediments: $\mathrm{NH}_{4}{ }^{+}$is converted into nitrate 
under the action of nitrifying bacteria, which is further converted into gaseous $\mathrm{N}$ by denitrifying bacteria [26,27]. The study of $\mathrm{Lu}$ et al. showed that, compared with an untreated system, the removal rate of $\mathrm{N}$ in the form of ammonia increased by $18 \%$ in the first $4 \mathrm{~h}$ after inoculation with nitrifying bacteria [44]. Therefore, the addition of nitrifying bacteria facilitates the process of nitrifying sediments and enhances nitrification activity, all of which play very important roles in improving the denitrification process of water bodies. In contrast, Mcilroy et al. [46] indicated that the addition of yeast had little effect on TN content in sediments. For bacilli, a part of the OM is converted into the bacterial matter during the decomposition process; however, a major share of the $\mathrm{OM}$ is converted into energy used by the bacteria [51]. Meanwhile, it is released from the water in the form of $\mathrm{N}$ and $\mathrm{CO}_{2}$, which reduces the ammonia-nitrogen and nitroso-nitrogen contents and restores the dissolved $\mathrm{O}$ levels within the water body [46].

The experimental results show that, although nitrifying bacteria can remove TP from sediments, when the dose of nitrifying bacteria was greater than a particular value, the removal rate of TP decreased. This occurred primarily because there was an increase in the matrix released into the environment with an increase in the dosage of the bacterial agent, which caused a low removal rate of TP during the reaction process [52].

Previous studies have shown that the main mechanisms that release $P$ from sediments are the following: a reduction in phosphate compounds within sediments under hypoxic conditions, a ligand exchange reaction occurring under a high $\mathrm{pH}$, and organophosphate mineralization [53]. Sediment plays a major role in the $\mathrm{P}$ cycle, and its exchange and transfer are accomplished through chemical reactions between the water and the sediment [54]. There are differences in the variability and bioavailability of $\mathrm{P}$ grades, and only $\mathrm{NH}_{4} \mathrm{Cl}-\mathrm{P}$ is easily assimilated and utilized. $\mathrm{NH}_{4} \mathrm{Cl}-\mathrm{P}$ is dissolved in interstitial water and easily desorbed and released into the overlying water by aeration disturbance. Bound P (BD$\mathrm{P}$ ) is the redox-sensitive state of $\mathrm{P}$, which is related to the redox state of the sediment. Furthermore, $\mathrm{P}$ is mainly bound to hydroxyl oxide and the theoretical molar ratio $\mathrm{Fe} / \mathrm{P}$ is close to 1 . When Fe (III) is reduced, the iron compounds are dissolved, and P is released [26].

\subsection{Removal of PAHs by Denitrifying Bacteria}

There are two main approaches used in the microbial metabolization of PAHs [55]: metabolization of PAHs when they are the only source of $\mathrm{C}$ and energy, and metabolization of PAHs along with other OM. PAHs comprised of three or fewer rings are generally metabolized using the first metabolic approach, whereas PAHs with four or more rings are generally metabolized using the second approach [56]. Compared to the control group, all the experimental groups with one of the three bacterial agents added exhibited PAH removal effects; however, Bacillus and yeast provided superior results. Previous studies have suggested that Bacillus can degrade PAHs as a $C$ source $[57,58]$; however, yeast tends to degrade PAHs through co-metabolism $[59,60]$. Under aerobic conditions, eukaryotes or prokaryotes produce oxygenase, which breaks the benzene ring and degrades or reduces the toxicity of PAHs; therefore, the ability to degrade PAHs is enhanced when the availability of oxygenase is increased. Microorganisms can also degrade PAHs via an anaerobic mechanism, and some anaerobic microorganisms can directly degrade small molecules of PAHs and often transform high-cycle PAHs through co-metabolism. Studies have shown that yeast can promote the removal of four kinds of PAHs in sediment (phenanthrene, anthracene, fluoranthene, and pyrene) [61]. The removal efficiency of PAHs is also affected by the duration that the microorganisms are exposed to the sediment [62], the nutrient concentration, and the anaerobic conditions $[59,63]$. Furthermore, low efficiency, high toxicity, extreme conditions (such as pressures between 6 and 11.2 MPa), high energy, and time consumption affect the degradation of PAHs. Therefore, studies are being conducted to find new methods that completely remove PAHs [63]. 


\subsection{Effect of Added Bacteria on Original Community Structure}

The composition of microbial river communities is diverse and dynamic, and it differs in relation to environmental factors [29]. Thus, the effect of the remediation method used on the microbial community of the sediment will influence the outcome [30], as the action mode of the microbes in the sediment changes when a microbial agent is added. In the CK2 column, Pseudomonas, which usually include a group of P-accumulating bacteria, was initially dominant, and the community then declined. During the experiment, the TP in the sediments first decreased and then, slightly increased. This likely occurred because the $\mathrm{P}$-accumulating bacteria adsorbed $\mathrm{P}$ in the early stage of the experiment; however, their population decreased in the later stage.

Under adverse conditions, $\mathrm{P}$-accumulating bacteria release $\mathrm{P}$, which results in a slight increase in the $\mathrm{P}$ concentration in sediments. Nitrite bacteria are generally known as "ammonia oxidizers" because they feed on ammonia, and the chemical energy generated by ammonia and oxidation is sufficient for their survival. Nitrosomonas can remove ammonia from aquatic ecosystems to form nitrite by oxidation. The removal of Nitrosomonas from the dominant species may be attributed to the consumption of ammonia, which acts as the food source for its survival in the system [64].

Syntrophus sp. is a type of hydrocarbon-degrading bacteria that are dominant in Mic2.2, and they may have a certain effect on the removal of certain PAHs in sediments [65]. The microorganisms occurring in high abundance within Mic2.4 were heterotrophic microorganisms that denitrified the sediment and used various organic compounds as their $\mathrm{C}$ and energy sources [46].

As shown in this study, some preliminary research results have been obtained in the laboratory. For sediment pollution with a certain scale of treatment, our quantitative research on key parameters such as temperature, salinity, $\mathrm{pH}$, and other indicators needs to be improved to improve the stability of large-scale sediment pollution treatment. However, for different river sediment, the factors affecting the removal efficiency are different, so we are carrying out further research to improve the scope of application of the research.

\section{Conclusions}

In this study, nitrifying bacteria, yeast, and Bacillus were applied and studied at various concentrations under laboratory conditions to determine the optimal type of microorganisms and their dosages for controlling the internal pollution of river sediments and remediating black-odorous water. The conclusions can be drawn as follows:

(1) Yeast was not effective in removing nitrogen or phosphorus from sediments. The best comprehensive removal rates of TN reached $27.65 \%$ and $20.88 \%$ when $5 \mathrm{mg}$ nitrifying bacteria and $10 \mathrm{mg}$ Bacillus respectively, were used. The ideal TP removal rates were as high as $24.70 \%$ and $39.67 \%$ respectively, when $5 \mathrm{mg}$ of nitrifying bacteria and $10 \mathrm{mg}$ of Bacillus were used. Nitrifying bacteria provided the best total nitrogen removal and Bacillus exhibited the best total phosphorus removal.

(2) The overall best efficiency in remediating organically contaminated sediment and removing nutrient pollutants and polycyclic aromatic hydrocarbons (PAHs) was obtained when using a $5 \mathrm{mg}$ dose of nitrifying bacteria.

(3) Up to 1203 OTUs remained in the sediments after remediation using Bacillus, and there were no significant variations in the microbial community structures among the sediment samples. Following remediation using nitrifying bacteria, Syntrophus sp. became the dominant bacteria in the sample, which may have had a certain effect on the removal of certain PAHs within the sediment.

Author Contributions: Conceptualization, F.W. and Y.B.; methodology, F.Y.; software, Q.Z. (Qianyu Zhao); validation, Q.Z. (Qiuheng Zhu) and X.Z.; formal analysis, F.W.; investigation, F.Y.; resources, X.Z.; data curation, X.Z.; writing—original draft preparation, F.W.; writing—review and editing, F.Y.; visualization, Y.W.; supervision, H.L.; project administration, F.Y.; funding acquisition, F.Y. All authors have read and agreed to the published version of the manuscript. 
Funding: This research was jointly supported by the National Natural Science Foundation of China (grant numbers YFC0409205, 51779117 and 41907338), and Postdoctoral Science Foundation of China (2019M660753), Welfare Scientific Subject of CRAES (grant numbers JY-2011ZX07212-007-001).

Institutional Review Board Statement: Not applicable.

Informed Consent Statement: Not applicable.

Acknowledgments: Special thanks go to anonymous reviewers for their detailed editing of the manuscript which greatly improved the readability of this work.

Conflicts of Interest: The authors declare no conflict of interest.

\section{References}

1. Li, L.-H.; Li, X.-Y.; Hong, Y.; Jiang, M.-R.; Lu, S.-L. Use of microalgae for the treatment of black and odorous water: Purification effects and optimization of treatment conditions. Algal Res. 2020, 47, 101851. [CrossRef]

2. Cao, J.; Sun, Q.; Zhao, D.; Xu, M.; Shen, Q.; Wang, D.; Wang, Y.; Ding, S. A critical review of the appearance of black-odorous waterbodies in China and treatment methods. J. Hazard. Mater. 2020, 385, 121511. [CrossRef] [PubMed]

3. Muyzer, G.; Stams, A.J.M. The ecology and biotechnology of sulphate-reducing bacteria. Nat. Rev. Genet. 2008, 6, 441-454. [CrossRef]

4. Rixen, T.; Baum, A.; Pohlmann, T.; Balzer, W.; Samiaji, J.; Jose, C. The Siak, a tropical black water river in central Sumatra on the verge of anoxia. Biogeochem. 2008, 90, 129-140. [CrossRef]

5. Hua, A.K.; Marsuki, M.Z. Public perception towards environmental awareness. Case study: Malacca River. Int. J. Acad. Res. Environ. Geogr. 2014, 1, 53-61. [CrossRef]

6. Khan, A.R.; Akif, M.; Khan, M.; Riaz, M. Impact of Industrial discharges on the quality of Kabul River water at Amangarh, Nowshera (Pakistan). J. Chem. Soc. Pak. 1999, 21, 97-105. Available online: https://jcsp.org.pk/ArticleUpload/1778-7971-1-PB. pdf (accessed on 27 February 2021).

7. Handa, S.; Jadhav, R. Status of Heavy metal pollution in Mithi river: Then and Now. Int. J. Res. Eng. Sci. 2016, 4, 62-68. Available online: https:/ / www.researchgate.net/publication/305905116_Status_of_Heavy_metal_pollution_in_Mithi_river_Then_and_ Now (accessed on 27 February 2021).

8. Le, T.N. Rethinking Urban Streams: Opportunities for the Nhieu Loc-Thi Nghe River, Urban Studies and Planning; Massachusetts Institute of Technology: Cambridge, MA, USA, 2008. Available online: https:/ /dspace.mit.edu/handle/1721.1/44331 (accessed on 27 February 2021).

9. Zhang, X. Discussion on typical cases and technical routes of black-odor river regulation in foreign countries. China Munic. Eng. 2018, 1, 36-39. (In Chinese) [CrossRef]

10. Chinese Ministry of Housing and Urban-Rural Development. Available online: http://www.hcstzz.com/ (accessed on 27 February 2021).

11. Wang, G.; Li, X.; Fang, Y.; Huang, R. Analysis on the formation condition of the algae-induced odorous black water agglomerate. Saudi J. Biol. Sci. 2014, 21, 597-604. [CrossRef] [PubMed]

12. Liang, Z.; Siegert, M.; Fang, W.; Sun, Y.; Jiang, F.; Lu, H.; Chen, G.-H.; Wang, S. Blackening and odorization of urban rivers: A bio-geochemical process. FEMS Microbiol. Ecol. 2018, 94, 1-12. [CrossRef]

13. Yu, D.; Xie, P.; Zeng, C.; Xie, L.; Chen, J. In Situ enclosure experiments on the occurrence, development and decline of black bloom and the dynamics of its associated taste and odor compounds. Ecol. Eng. 2016, 87, 246-253. [CrossRef]

14. Caraco, N.F.; Cole, J.J.; Likens, G.E. Evidence for sulphate-controlled phosphorus release from sediments of aquatic systems. Nat. Cell Biol. 1989, 341, 316-318. [CrossRef]

15. Jarvie, H.P.; Jürgens, M.D.; Williams, R.J.; Neal, C.; Davies, J.J.; Barrett, C.; White, J. Role of river bed sediments as sources and sinks of phosphorus across two major eutrophic UK river basins: The Hampshire Avon and Herefordshire Wye. J. Hydrol. 2005, 304, 51-74. [CrossRef]

16. Nykänen, A.; Kontio, H.; Klutas, O.; Penttinen, O.-P.; Kostia, S.; Mikola, J.; Romantschuk, M. Increasing lake water and sediment oxygen levels using slow release peroxide. Sci. Total. Environ. 2012, 429, 317-324. [CrossRef] [PubMed]

17. Jing, L.D.; Wu, C.X.; Liu, J.T.; Wang, H.G.; Ao, H.Y. The effects of dredging on nitrogen balance in sediment-water microcosms and implications to dredging projects. Ecol. Eng. 2013, 52, 167-174. [CrossRef]

18. Yin, H.; Wang, J.; Zhang, R.; Tang, W. Performance of physical and chemical methods in the co-reduction of internal phosphorus and nitrogen loading from the sediment of a black odorous river. Sci. Total. Environ. 2019, 663, 68-77. [CrossRef] [PubMed]

19. Liu, X.; Tao, Y.; Zhou, K.; Zhang, Q.; Chen, G.; Zhang, X. Effect of water quality improvement on the remediation of river sediment due to the addition of calcium nitrate. Sci. Total. Environ. 2017, 575, 887-894. [CrossRef]

20. Yin, H.; Yang, P.; Kong, M. Effects of nitrate dosing on the migration of reduced sulfur in black odorous river sediment and the influencing factors. Chem. Eng. J. 2019, 371, 516-523. [CrossRef]

21. Fabiano, M.; Marrale, D.; Misic, C. Bacteria and organic matter dynamics during a bioremediation treatment of organic-rich harbour sediments. Mar. Pollut. Bull. 2003, 46, 1164-1173. [CrossRef] 
22. Liu, M.; Ran, Y.; Peng, X.; Zhu, Z.; Liang, J.; Ai, H.; Li, H.; He, Q. Sustainable modulation of anaerobic malodorous black water: The interactive effect of oxygen-loaded porous material and submerged macrophyte. Water Res. 2019, 160, 70-80. [CrossRef]

23. Jiang, J.; Wang, Y.; Liu, J.; Yang, X.; Ren, Y.; Miao, H.; Pan, Y.; Lv, J.; Yan, G.; Ding, L.; et al. Exploring the mechanisms of organic matter degradation and methane emission during sewage sludge composting with added vesuvianite: Insights into the prediction of microbial metabolic function and enzymatic activity. Bioresour. Technol. 2019, 286, 121397. [CrossRef] [PubMed]

24. Zhu, Q.; Li, X.; Li, G.; Li, J.; Li, C.; Che, L.; Zhang, L. Enhanced bioenergy production in rural areas: Synthetic urine as a pre-treatment for dry anaerobic fermentation of wheat straw. J. Clean. Prod. 2020, 260, 121164. [CrossRef]

25. Revsbech, N.P.; Jacobsen, J.P.; Nielsen, L.P. Nitrogen transformations in microenvironments of river beds and riparian zones. Ecol. Eng. 2005, 24, 447-455. [CrossRef]

26. Schauser, I.; Chorus, I.; Lewandowski, J. Effects of nitrate on phosphorus release: Comparison of two Berlin lakes. Clean Soil Air Water 2006, 34, 325-332. [CrossRef]

27. Yamada, T.M.; Sueitt, A.P.E.; Beraldo, D.A.S.; Botta, C.M.R.; Fadini, P.S.; Nascimento, M.R.L.; Faria, B.M.; Mozeto, A.A Calcium nitrate addition to control the internal load of phosphorus from sediments of a tropical eutrophic reservoir: Microcosm experiments. Water Res. 2012, 46, 6463-6475. [CrossRef]

28. Cai, W.; Li, Y.; Shen, Y.; Wang, C.; Wang, P.; Wang, L.; Niu, L.; Zhang, W. Vertical distribution and assemblages of microbial communities and their potential effects on sulfur metabolism in a black-odor urban river. J. Environ. Manag. 2019, 235, 368-376. [CrossRef]

29. Ibekwe, A.M.; Ma, J.; Murinda, S.E. Bacterial community composition and structure in an Urban River impacted by different pollutant sources. Sci. Total. Environ. 2016, 566, 1176-1185. [CrossRef]

30. Wang, W.-H.; Wang, Y.; Fan, P.; Chen, L.-F.; Chai, B.-H.; Zhao, J.-C.; Sun, L.-Q. Effect of calcium peroxide on the water quality and bacterium community of sediment in black-odor water. Environ. Pollut. 2019, 248, 18-27. [CrossRef] [PubMed]

31. Zhu, Q.; Wu, L.; Li, X.; Li, G.; Li, J.; Li, C.; Zhao, C.; Wang, F.; Du, C.; Deng, C.; et al. Effects of ambient temperature on the redistribution efficiency of nutrients by desert cyanobacteria- Scytonema javanicum. Sci. Total. Environ. 2020, 737, 139733. [CrossRef]

32. Li, W.; Zhang, S.; Zhang, L.; Li, X.; Wang, F.; Li, G.; Li, J.; Li, W. In-situ remediation of sediment by calcium nitrate combined with composite microorganisms under low-DO regulation. Sci. Total. Environ. 2019, 697, 134109. [CrossRef]

33. Wang, Z.; Yang, Y.; Sun, W.; Xie, S.; Liu, Y. Nonylphenol biodegradation in river sediment and associated shifts in community structures of bacteria and ammonia-oxidizing microorganisms. Ecotoxicol. Environ. Saf. 2014, 106, 1-5. [CrossRef]

34. Guo, Q.; Yan, J.; Wen, J.; Hu, Y.; Chen, Y.; Wu, W. Rhamnolipid-enhanced aerobic biodegradation of triclosan (TCS) by indigenous microorganisms in water-sediment systems. Sci. Total. Environ. 2016, 571, 1304-1311. [CrossRef]

35. Pringault, O.; Viret, H.; Duran, R. Influence of microorganisms on the removal of nickel in tropical marine sediments (New Caledonia). Mar. Pollut. Bull. 2010, 61, 530-541. [CrossRef]

36. Zhang, Y.-Z.; Wang, B.; Wang, W.; Li, W.-C.; Huang, J.; Deng, S.-B.; Wang, Y.-J.; Yu, G. Occurrence and source apportionment of Per- and poly-fluorinated compounds (PFCs) in North Canal Basin, Beijing. Sci. Rep. 2016, 6, 36683. [CrossRef] [PubMed]

37. Chinese Ministry of Ecology and Environment. Soil-Determination of Ammonium, Nitrite and Nitrate by Extraction with Potassium Chloride Solution-Spectrophotometric Methods, 2012. Available online: http:/ /www.mee.gov.cn/ywgz/fgbz/bz/ bzwb/jcffbz/201203/t20120307_224381.shtml (accessed on 27 February 2021). (In Chinese)

38. Chinese Ministry of Ecology and Environment. Soil-Determination of Total Phosphorus by Alkali Fusion-Mo-Sb Anti Spectrophotometric Method. 2011. Available online: http://www.mee.gov.cn/ywgz/fgbz/bz/bzwb/jcffbz/201112/t20111213_221313.shtml (accessed on 27 February 2021). (In Chinese)

39. Chinese Ministry of Ecology and Environment. Soil—Determination of Organic Carbon-Combustion Oxidation-Titration Method. 2013. Available online: http://www.mee.gov.cn/ywgz/fgbz/bz/bzwb/jcffbz/201308/t20130820_257715.shtml (accessed on 27 February 2021). (In Chinese)

40. Chinese Ministry of Ecology and Environment. Soil and Sediment-Determination of Polycyclic Aromatic Hydrocarbons-High Performance Liquid Chromatography. 2016. Available online: http://www.mee.gov.cn/ywgz/fgbz/bz/bzwb/jcffbz/201602/t2 0160217_330303.shtml (accessed on 27 February 2021). (In Chinese)

41. Edgar, R.C. UPARSE: Highly accurate OTU sequences from microbial amplicon reads. Nat. Methods 2013, 10, 996-998. [CrossRef]

42. Stackebrandt, E.; Goebel, B.M. Taxonomic Note: A Place for DNA-DNA Reassociation and 16S rRNA Sequence Analysis in the Present Species Definition in Bacteriology. Int. J. Syst. Evol. Microbiol. 1994, 44, 846-849. [CrossRef]

43. Wang, Q.; Garrity, G.M.; Tiedje, J.M.; Cole, J.R. Naïve Bayesian Classifier for Rapid Assignment of rRNA Sequences into the New Bacterial Taxonomy. Appl. Environ. Microbiol. 2007, 73, 5261-5267. [CrossRef]

44. Lu, X.-Y.; Li, B.; Zhang, T.; Fang, H.H. Enhanced anoxic bioremediation of PAHs-contaminated sediment. Bioresour. Technol. 2012, 104, 51-58. [CrossRef]

45. Chang, S. Bio-Remediation Technology Used on Remediating the Urban River, Tianjin University, 2011. Available online: https: / / kns.cnki.net/kcms / detail/detail.aspx?dbcode=CDFD\&dbname=CDFD1214\&filename=1012007423.nh\&v=cussKEt6 1d3S1xm0brUYdqE7aFCKdNLTp8zItBLDDUzGSRkhZdh2kAhn\%25mmd2Be\%25mmd2BrqlrA (accessed on 27 February 2021). (In Chinese)

46. McIlroy, S.J.; Starnawska, A.; Starnawski, P.; Saunders, A.M.; Nierychlo, M.; Nielsen, P.H.; Nielsen, J.L. Identification of active denitrifiers in full-scale nutrient removal wastewater treatment systems. Environ. Microbiol. 2014, 18, 50-64. [CrossRef] [PubMed] 
47. Bichoff, A.; Osório, N.C.; Ruwer, D.T.; Dunck, B.; Rodrigues, L. Trait structure and functional diversity of periphytic algae in a floodplain conservation area. Braz. J. Bot. 2018, 41, 601-610. [CrossRef]

48. Chen, L.; Wang, L.-Y.; Liu, S.-J.; Hu, J.-Y.; He, Y.; Zhou, H.-W.; Zhang, X.-H. Profiling of microbial community during in situ remediation of volatile sulfide compounds in river sediment with nitrate by high throughput sequencing. Int. Biodeterior. Biodegrad. 2013, 85, 429-437. [CrossRef]

49. Chen, Y.; Jiang, Y.; Huang, H.; Mou, L.; Ru, J.; Zhao, J.; Xiao, S. Long-term and high-concentration heavy-metal contamination strongly influences the microbiome and functional genes in Yellow River sediments. Sci. Total. Environ. 2018, 1400-1412. [CrossRef] [PubMed]

50. Gao, Y.; Xie, Y.; Zhang, Q.; Wang, A.; Yu, Y.; Yang, L. Intensified nitrate and phosphorus removal in an electrolysis -integrated horizontal subsurface-flow constructed wetland. Water Res. 2017, 108, 39-45. [CrossRef] [PubMed]

51. Feng, Z.; Fan, C.; Huang, W.; Ding, S. Microorganisms and typical organic matter responsible for lacustrine "black bloom". Sci. Total. Environ. 2014, 470, 1-8. [CrossRef]

52. Wu, J.-H.; Chen, W.-Y.; Kuo, H.-C.; Li, Y.-M. Redox fluctuations shape the soil microbiome in the hypoxic bioremediation of octachlorinated dibenzodioxin and dibenzofuran-contaminated soil. Environ. Pollut. 2019, 248, 506-515. [CrossRef]

53. Zhang, B.; Fang, F.; Guo, J.; Chen, Y.; Li, Z.; Guo, S. Phosphorus fractions and phosphate sorption-release characteristics relevant to the soil composition of water-level-fluctuating zone of Three Gorges Reservoir. Ecol. Eng. 2012, 40, 153-159. [CrossRef]

54. Duan, H.; Ma, R.; Loiselle, S.A.; Shen, Q.; Yin, H.; Zhang, Y. Optical characterization of black water blooms in eutrophic waters. Sci. Total. Environ. 2014, 482, 174-183. [CrossRef]

55. Xu, M.; Zhang, Q.; Xia, C.; Zhong, Y.; Sun, G.; Guo, J.; Yuan, T.; Zhou, J.; He, Z. Erratum: Elevated nitrate enriches microbial functional genes for potential bioremediation of complexly contaminated sediments. ISME J. 2015, 9, 532. [CrossRef]

56. Haritash, A.; Kaushik, C. Biodegradation aspects of Polycyclic Aromatic Hydrocarbons (PAHs): A review. J. Hazard. Mater. 2009, 169, 1-15. [CrossRef]

57. Bahuguna, A.; Lily, M.K.; Dangwal, K.; Munjal, A.; Singh, R.N. Degradation of Naphthalene by a novel strain Bacillus licheniformis BMIT5ii (MTCC 9446). J. Pharm. Res. 2012, 5, 1600-1604. Available online: http://jprsolutions.info/newfiles/journal-file-56af611 51f8987.99790745.pdf (accessed on 27 February 2021).

58. Li, L.; Zhong, M.; Zhou, Q.; Li, K.; Yang, Z.; Jiang, S. Study on Characteristics of Bacillus subtilis strainII for the Degradation of Polycyclic Aromatic Hydrocarbons. J. Henan Agric. Sci. 2007, 4, 62-64. Available online: https://kns.cnki.net/kcms/detail/detail. aspx?dbcode=CJFD\&dbname=CJFD2007\&filename=HNNY200704021\&v=aH6uvbAChXNhGxlv6vXgqQh8\%25mmd2FJ4tK9 3LnHChpMvT5b6v5LuO\%25mmd2BYTUrWiTa6tLA40D (accessed on 27 February 2021). (In Chinese)

59. Hesham, A.E.-L.; Khan, S.; Tao, Y.; Li, D.; Zhang, Y.; Yang, M. Biodegradation of high molecular weight PAHs using isolated yeast mixtures: Application of meta-genomic methods for community structure analyses. Environ. Sci. Pollut. Res. 2012, 19, 3568-3578. [CrossRef]

60. Tam, N.; Ke, L.; Wang, X.; Wong, Y. Contamination of polycyclic aromatic hydrocarbons in surface sediments of mangrove swamps. Environ. Pollut. 2001, 114, 255-263. [CrossRef]

61. Zhang, X.-J.; Chen, C.; Ding, J.-Q.; Hou, A.; Li, Y.; Niu, Z.-B.; Su, X.-Y.; Xu, Y.-J.; Laws, E.A. The 2007 water crisis in Wuxi, China: Analysis of the origin. J. Hazard. Mater. 2010, 182, 130-135. [CrossRef] [PubMed]

62. Kumari, S.; Regar, R.K.; Manickam, N. Improved polycyclic aromatic hydrocarbon degradation in a crude oil by individual and a consortium of bacteria. Bioresour. Technol. 2018, 254, 174-179. [CrossRef] [PubMed]

63. Al-Hawash, A.B.; Dragh, M.A.; Li, S.; Alhujaily, A.; Abbood, H.A.; Zhang, X.; Ma, F. Principles of microbial degradation of petroleum hydrocarbons in the environment. Egypt. J. Aquat. Res. 2018, 44, 71-76. [CrossRef]

64. Ma, Q.; Qu, Y.; Shen, W.; Zhang, Z.; Wang, J.; Liu, Z.; Li, D.; Li, H.; Zhou, J. Bacterial community compositions of coking wastewater treatment plants in steel industry revealed by Illumina high-throughput sequencing. Bioresour. Technol. 2015, 179, 436-443. [CrossRef]

65. Fernández, N.; Sierra-Alvarez, R.; Field, J.A.; Amils, R.; Sanz, J.L. Microbial community dynamics in a chemolithotrophic denitrification reactor inoculated with methanogenic granular sludge. Chemosphere 2008, 70, 462-474. [CrossRef] 